\title{
The Triassic-Jurassic boundary in Great Britain
}

SIR - The recent suggestion that in Britain 'the base of the Hettangian (and the Jurassic) be lowered to the top of the Cotham Beds' (Poole, 1979, p. 310) invites further comment since we consider that the lithostratigraphical junction of two local facies should not be used to define the base of a system.

Our understanding of the proposal by George et al. $(1969$, p. 160), that 'the base of the Blue Lias ...in the Watchet area... should be considered for formal adoption as the type of the [Planorbis Standard Chrono-]zone, of the Hettangian stage, and of the Jurassic system', differs from that of the author. By definition, the base of a chronozone cannot be diachronous in the way the latter implies. Unfortunately, the suggestion of a locally restricted lithostratigraphical boundary as the marker point for the base of the chronozone has contributed to an erroneous assumption that the proposers' intention was to make the base of the chronozone (and hence of the Jurassic) everywhere coincident with the base of the Blue Lias or its lithostratigraphical correlatives. Their intention was that the 'marker point' should be at the base of the Planorbis Zone and in this context the local base of the 'Blue Lias' in the Watchet area could be a possible horizon-because it lay at about that level in an area of good exposures and of historical association with the zonal index fossil.

Re-definition of the 'pre-planorbis Beds' by Poole (1979), extending the usage lithostratigraphically and its application geographically, is undesirable because nomenclatoral confusion would occur. Indeed, although it has informal value for a well-known local sequence of historical importance, the name should be abandoned because its upper limit is defined biostratigraphically.

The interpretation of the relationship of late Triassic and early Jurassic strata to the London Platform illustrated by Poole (1979, fig. 1, p. 304) differs significantly from that given by Donovan, Horton \& Ivimey-Cook (1979), in which the nature of the south-easterly onlap of early Jurassic biozones on to this 'platform' is illustrated.

The ranges of certain fossils, principally bivalves, are used by Poole $(1979$, p. 306$)$ as age indicators. However, the foraminifer Eoguttulina liassica (Strickland) and the bivalves Dimyopsis intusstriata (Emmerich), 'Gervillia' praecursor (Quenstedt), Liostrea, Modiolus hillanoides (Chapuis \& Dewalque) [olim. Volsella langportensis Richardson \& Tutcher, nom. nov. for M. minimus Moore non Sowerby], 'Pleurophorus' elongatus Moore, and Protocardia occur in the Westbury Beds and /or the Cotham Beds and thus are not diagnostic of higher strata as suggested by Poole.

As the review by Poole demonstrates, it would be inadvisable to attempt a definition of the base of the Planorbis Chronozone anywhere between the Cotham Beds and the lowest occurrence of Psiloceras in the British Isles, whatever the conceptual basis used. In defining the position of this base there are, therefore, three alternatives - $(a)$ within or below the Cotham Beds; $(b)$ the top of the Cotham Beds; $(c)$ the lowest occurrence of Psiloceras.

Poole gives valid reasons (p. 110) for rejecting alternative (a), but ignores one of these reasons - 'since the age of this formation is unknown in terms of the ammonite sequence' - in advocating alternative (b). This latter alternative is open to criticism in several other respects. It disregards many of the recommendations for establishing chronostratigraphical boundaries (e.g. the preference for locations within sequences of essentially continuous deposition, the avoidance of unconformities and erosion surfaces, the need for evidence applicable to long-distance (i.e. international, not merely national or local) time correlation, etc.; see Hedberg, 1976, pp. 82 et seq.). It also invokes mappability, a factor largely irrelevant to chronostratigraphy. A less tangible but nevertheless important objection is that, in pleading a special case and consequently blurring the distinction between chronostratigraphy and lithostratigraphy, alternative $(b)$ sets an undesirable example with regard to a system (the Jurassic), the nomenclature and classification of which have suffered more than most others from special cases and blurred stratigraphical concepts.

Alternative $(c)$, defining the base of the Planorbis Chronozone (and of the Jurassic System) at the lowest occurrence of Psiloceras in a suitable stratotype sequence, avoids all these criticisms and by utilizing widely available biostratigraphical evidence conforms to the method used elsewhere throughout the Jurassic and in other systems for defining chronostratigraphical boundaries. Freeswimming organisms such as ammonites are probably able to colonize marine areas rapidly, particularly if those areas are devoid of related taxa. Whittaker (1976) reported that Psiloceras appears in profusion at virtually the same lithostratigraphical level over a large area of southern England.

0016-7568/80/2828-6060 \$01.00 (C) 1980 Cambridge University Press

Geol. Mag. 117 (6), 1980, pp. 617-620. Printed in Great Britain 
The sections illustrated by Poole (1979, fig. 3, p. 307) demonstrate the wide applicability of this ever.t, which the I.G.S. Humber and Acklam area boreholes extend to the area $S$ and $N$ of the Market Weighton structure (Gaunt et al. 1980). In the absence of any other, demonstrably more reliable, evidence, the incoming of Psiloceras appears to be the best available indicator of a synchronous event.

The internationally widespread occurrence of Psiloceras has been noted (Donovan, Horton \& Ivimey-Cook, 1979) and the base of the Psiloceras planorbis biozone is generally accepted as a biostratigraphical indication of the base of the Jurassic. Ideally, an international stratotype in a continuous sequence with both Rhaetian and Hettangian ammonites is needed but as yet none is forthcoming. We understand that the Geological Society of London's Jurassic Working Group in its forthcoming Special Report 'A correlation of Jurassic rocks in the British Isles' proposes that the base of the Planorbis Chronozone (and the Jurassic System) be taken at the lowest occurrence of Psiloceras in a stratotype section in the Watchet area of Somerset. Although this section is not ideal, it is clearly the best British candidate for the international stratotype. This approach is also adopted in the report 'A correlation of Triassic rocks in the British Isles' by Warrington et al. (Spec. Re, . Geol. Soc. Lond. no. 13, 1980).

\section{References}

Donovan, D. T., Horton, A. \& Ivimey-Cook, H. C. 1979. The transgression of the Lower Lias over the northern flank of the London Platform. Jl. geol. Soc. Lond. 136, 165-73.

Gaunt, G. D., Ivimey-Cook, H. C., Penn, I. E. \& Cox, B. M. 1980. Mesozoic rocks proved by IGS boreholes in the Humber and Acklam areas. Rep. Inst. Geol. Sci. no. 79/13.

George, T. N. et al. 1969. Recommendations on stratigraphical usage. Proc. geol. Soc. Lond. no. 165i5, pp. 139-66.

Hedberg, H. D. 1976. International Stratigraphic Guide: A Guide to Stratigraphic Classification, Terminology and Procedure. New York: J. Wiley.

Poole, E. G. 1979. The Triassic-Jurassic boundary in Great Britain. Geol. Mag. 116, 303-11.

Whittaker, A. 1976. The distribution of the ammonite Psiloceras planorbis in S.W. Britain (abstract), Proc. Ussher Soc. 3, p. 360.
H. C. Ivimey-Cook
I.G.S.
G. D. Gaunt
I.G.S.
Exhibition Road,
Ring Road Halton,
G. W. Green
London.
Leeds.
I.G.S.
Keyworth, Nottingham.
A. Horton
G. Warrington
I.G.S.
I.G.S.
A. Whittaker
I.G.S.
5 Princes Gate,
Ring Road Halton,
Keyworth
London.
Leeds.
Nottingham.

(Published by permission of the Director, Institute of Geological Sciences, London.)

24th March 1980

SIR - I refer to E. G. Poole's interesting paper on the above-named topic in which he summarizes the characters of the earliest beds of the Lias in the Midlands and adjacent areas (Poole, 1979). I write to comment on his proposal to include the White Lias in the Pre-planorbis Beds, from the point of view of one who has worked in the type area of the White Lias, formerly north Somerset, now mainly the County of Avon. The term White Lias was first used in a stratigraphical sense near Bath by Willian Smith (MS Table of Strata, 1799, Geological Society of London) and first published with an indication of stratigraphical position by Warner (1811). Where most fully developed, in the area W and SW of Bath, it consists of two approximately equal parts: the lower is rubbly limestone with clay partings, the upper strong, hard, fine-grained limestones, with thin clay partings. The base is drawn above the horizon of nodules of algal colonies known as the Cotham Marble. The top is formed by a thick limestone, the Sun Bed, which may reach $1 \mathrm{ft} 6$ in $(0.46 \mathrm{~m})$ in thickness and bears vertical U-shaped burrows at most exposures. In general the rocks are barren of fossils but there is a limited fauna of marine bivalves, gastropods and ostracods, chiefly from the lower division. The thickness is greatest (about $18 \mathrm{ft} ; 5.5 \mathrm{~m}$ ) around Radstock. The White Lias wedges out to the $\mathrm{S}$ against the Mendips anc., more gradually, to the $\mathrm{N}$ of Bristol. 
The Pre-planorbis Beds were defined by Richardson (1904, p. 36) in the Tewkesbury area where the White Lias is absent. He used the term for beds between the top of his Upper Rhaetic (i.e. the Pseudomonotis bed or 'Insect Limestone' of Garden Cliff, Westbury-on-Severn and adjacent areas) and the lowest beds with ammonites. In the type area of the White Lias the term Pre-planorbis Beds was not generally used, but all authors describing relevant sections recognized a group of beds above the massive limestones of the White Lias and below the lowest beds with ammonites; these were named Pleuromya and Ostrea Beds by Tutcher $(1908$, p. 6) and are the Ostrea Beds of Donovan (1956, p. 108). These Ostrea Beds are thin, irregular, coarse, shelly limestones with an abundant bivalve fauna (about 18 species), with shaly partings. They are sharply delimited from the White Lias below, the top of the Sun Bed usually being a planed surface. Near Marksbury there were signs of channelling of the White Lias before deposition of the Ostrea Beds (G. A. Kellaway, personal communication). Their upper limit is less well defined, as the ammonite Psiloceras may not enter at a constant horizon. In most sections, however, it appears in a conspicuous bed known as the Psiloceras Bed. The thickness of beds between the top of the White Lias and the Psiloceras Bed is greatest (about $7 \mathrm{ft} ; 2.1 \mathrm{~m}$ ) S and SE of Bristol (Donovan, 1956, p. 198) where the White Lias is thin. The Ostrea Beds are distinct from the White Lias both in their lithology and in their pattern of sedimentation, and there is always a sharp boundary between them. There is no evidence for lateral passage or facies change from one to the other in Avon.

I have sought to show, briefly, the dissimilarity and independent behaviour of the White Lias and Ostrea Beds in the type area of the former. In Avon it does not make sense to group them together as Pre-planorbis Beds, which would follow from the adoption of Poole's proposal. I do not comment on areas further $\mathbf{N}$ where Poole has chiefly worked and which I do not know. It may be that the term Pre-planorbis Beds should be restricted to the area for which it was proposed, or preferably abolished altogether. It is, in any case, an unsatisfactory term. An alternative solution would be for Poole to propose a new lithostratigraphical classification for the Midlands.

I do not wish to comment here on the question of the base of the Jurassic System, which is a separate problem. Poole's proposal $(1979$, p. 310$)$ amounts to taking it at the base of the White Lias (where present) or at the base of the Pre-planorbis Beds, and can be considered apart from his proposal as to the lithostratigraphical classification of the White Lias. It is, in the last resort, an arbitrary decision for British geologists because the faunas of the beds above the Westbury Formation and below the first entry of the ammonite Psiloceras are of no use for precise biostratigraphical classification.

\section{References additional to above}

Donovan, D. T. 1956. The zonal stratigraphy of the Blue Lias around Keynsham, Somerset. Proc. geol. Assoc. Lond. 66, 182-212.

Richardson, L. 1904. A Handbook to the Geology of Cheltenham and Neighbourhood. Cheltenham. Tutcher, J. W. 1908. The strata exposed in constructing the Filton to Avonmouth railway. Proc. Bristol Nat. Soc. (4th ser.) 2, 5-21.

Warner, R. 1811. A New Guide to Bath and Its Environs. Bath.

Department of Geology

D. T. DONOVAN

University College London

London WC1E 6BT

27th March 1980

SIR - In reply to the comments made by Donovan and Ivimey-Cook (above) I repeat that, in the absence of a proper base to the Psiloceras planorbis Subzone in Great Britain, it is illogical to take the Jurassic boundary here. If my critics are indeed interested in a uniform international boundary then they should support that one taken at the top of the Rhaetic Cotham Beds since it is the same horizon as that taken in the North Sea (top of Winterton Sandstone) and in North Germany (top of the Rhaetic Sandstone). Furthermore, our German colleagues have recently discovered ammonites in the intervening strata below Psiloceras planorbis but they have not raised their Triassic-Jurassic boundary as a consequence.

There is plenty of excellent, practical precedence for taking major boundaries at lithological horizons which record synchronous change. In the Carboniferous, Stage boundaries are taken at the 
change from non-marine to marine strata (and vice versa), not at the entry of the goniatite within the marine band concerned and in many places these marker horizons do not even contain the diagnostic goniatite. Where the marine band is fully developed, however, there are generally a few metres of basal Lingula-bearing beds before goniatites occur. The pre-planorbis Beds may be regarded in exactly the same way, these are shallow-water deposits with a limited fauna laid down before the sea deepened enough or geographical barriers were removed to allow the entry of ammonites. It has not been proved that Psiloceras planorbis appears everywhere simultaneously (see also Professor Donovan's remark s) and I remain convinced that widespread epeirogenetic earth-movements such as occurred during the Carboniferous and at the close of the Rhaetic are much more likely to be synchronous.

I agree with Professor Donovan that the White Lias is a unique facies. It is normally a very high purity shallow-water limestone which was precipitated in quiet, sheltered clear waters. Although fossils are generally few, its fauna is exactly the same as that of the muddier pre-planorbis Beds. It thickers in the vicinity of the old shoreline from Warwickshire to the Mendips and disappears into the Worcester Basin. In places it contains thin muddy bands and apparently maps into pre-planorbis Becls with Ostrea limestones near Stratford-on-Avon. It is underlain in places by a thin but widespread black shale horizon crowded with the same fossils as the pre-planorbis Beds which rests in turn directly upon the Cotham Beds. The White Lias limestone also has a sharply eroded upper surface in paris of Oxfordshire and Warwickshire due to local uplift of the London Platform; here it is directly overlain by strata containing Psiloceras planorbis.

'Hy-a-lea' Dover Terrace

E. G. POOLE

Christ Church

Barbados

27th April 1980 